\title{
Ecological Security in Lithuania: The Current Situation and Problems
}

\begin{abstract}
In 2006, the trends in the change of ecological risk factors in Lithuania were similar to those of 2005. The risk factors, which contributed to the change of the state's ecological condition in the field of the atmosphere protection, included the rapidly growing number of automobiles, inefficient city traffic control systems, and the lack of bypasses, whereas the risks in the sector of water consumption safety were posed by a worn out central water supply networks, insufficient quality of the drinking water and dug well water. Thus, the objectives set down in the National Ecological Security Assurance Programme are to reduce ecological risk, prevent a negative impact on the environment and to set the national priorities in the sphere of the prevention of emergencies.

The tasks crucial for the implementation of the state's priorities are related to ensuring ecological security by securing sustainable economic development and reducing the negative impact of an emergency on the environment and residents. Dissemination of objective information on ecological security, collection and analysis of reliable information and its disclosure to the public will encourage the cooperation with neighbouring countries in the spheres of ecological security and pollution prevention. In order to accomplish the set objectives, i.e. to ensure ecological security, it is necessary to create legal and institutional conditions for mutual coordination, management and control of actions for the responsible institutions.
\end{abstract}

\section{Introduction}

Scientific and technical progress, as well as the mans' possibilities to have an influence on nature, have begun to overpower the abilities to understand and evaluate possible outcomes of this activity. Rapid economic growth (economic development) has highlighted global problems, which reflect the state of Lithuania's economic, political, and inner life. Current politics has to ensure that activities of one human generation will not reduce the possibilities of future generations, since certain essential properties of environmental and social systems, if damaged, cannot be easily restored. ${ }^{1}$ Damage to the natural environment as a result of economic development is one of the key problems with this period.

In 2003 the Lithuanian Government approved the National Sustainable

\footnotetext{
*Irena Gavéniené, Environmental Protection Expert, Lecturer at the International Business School (IBS) at Vilnius University, Saulètekio ave. 22, LT-10225, pone: (8-5) 2732882, mobile phone. 8-685 37111, e-mail: irena@gavenas.com

${ }^{1}$ Čiegis R., Ecological Security: New Challenges to the Planet, Strateginè savivalda, ISSN 1648-5815 Strategic Self-Management 2006 Nr. 1(3), http://www.eksponente.lt/ssz
} 
Development Strategy (NSDS) thus acknowledging environmental protection as one of the key components in the development of the state. The main challenge of sustainable development in Lithuania is to achieve the present developmental level of EU countries, according to indicators of economic and social development as well as the efficiency in consumption of natural resources, and not to exceed allowable EU standards, according to indicators of environmental pollution, while meeting the requirements of international conventions in the field of minimization of environmental pollution and input into global climate change. However, modern industrial society and its development model are definitely inharmonious, since economic activity is based on non-renewable resources and fossil fuel, the use of natural resources is clearly too extensive, the distribution of income and resources among the population is uneven, and the income gap between industrial and developing countries is gradually widening, which catches around 3 billion people in the trap of absolute poverty. Hence, economic development has highlighted two major global problems, poverty and military conflicts. These negative aspects that surfaced during the development of society are mutually reinforcing: poverty forces people to overexploit the environment (the fundamental long-term connection between poverty and environmental degradation was acknowledged already at the end of 1980s and became the major challenge to sustainable development), poverty leads to conflicts, conflicts inflict environmental damage, and the damaged environment and limitations in turn cause social conflicts. Therefore, the occurrence of ecological problems should be analysed as the outcome of these processes occurring in the economic, social and environmental protection system. ${ }^{2}$

Essentially, the internal and external factors that ensure national security of the Republic of Lithuania have not changed which allows maintaining that social and economic development forms the basis for social stability and reduction of external threat possibilities. In 2006, the trends in change of ecological factors did not alter significantly (polluted territories were not cleaned, the number of landfills that do not comply with the EU requirements remained large, the problems of worn-out central water supply networks, lack of bypasses, and air pollution were not solved, etc.). The main external threats faced by Lithuania remain momentary natural disasters, such as downpours, strong winds, storms, lasting frost, and the increasing number of fires breaking out in open areas (their number increased 2.4 times in 2006).

Achieving the balance between the rapid economic growth and the necessity to maintain healthy environment is quite a difficult task, since the public usually tends to concentrate on solving economic problems, which is frequently done at the expense of environmental quality. At the current stage of the state's development it is highly important to ensure the timely implementation of effective environmental protection measures and to reduce the negative impact of the use of energy and natural resources and economic activities on the environment. The costs of solving the accumulated problems are much greater than

\footnotetext{
${ }^{2}$ Ibidem.
} 
the prevention costs and might hinder the economic growth in the long-term. Therefore, in order to ensure sustainable development and better quality of the environmental, attention and funds should be allotted for priority trends of environmental protection and pollution prevention in the first place.

\section{The Current State of the Environment}

The geographical location and structure of the territory of the Republic of Lithuania is favourable to harmonious development of society; its natural conditions do not pose any threat to the existence of the nation or the state. The amount of the main pollutants released to the surface water bodies decreased by over 50 per cent in the last years (surface and underground water bodies as well as the area of Lithuanian territory in the Baltic Sea make up around 413 sq kilometres. However, only 40 per cent of wastewater is treated according to the established norms (data of 2005) since the majority of wastewater treatment facilities are physically outdated. Existing water supply networks are worn out (some of them are 50 or 70 years old) and need renovation. Otherwise, the quality of centrally supplied drinking water will not be ensured, which might increase the risk to public health. The industrial enterprises' consumption of energy, raw materials and water per production of GDP unit is 1.5 - 2 times higher than the average in EU member states.

The amount of emissions into the air from stationary sources decreased by around 60 per cent over the last decade, however, automobiles, the majority of which in Lithuania are still over ten years old, outdated and inefficient traffic control systems as well as the lack of bypasses increase urban air pollution and noise, especially in the central parts of the cities. There are no repositories of natural gas and only one source of gas supply is used (it provides 90 per cent of gas) which poses a threat that the reduction of gas supply or the increase in gas prices will encourage the use of a more polluting fuel. Energy use and air pollution per production of one GDP unit in Lithuanian is up to 2 times higher than in other EU member states.

The annually generated non-hazardous and hazardous waste amount to 3.5 million tons and 110 million tons respectively. The majority of waste is disposed of in landfills, the municipal waste management system is insufficiently developed, and most of the currently operating landfills do not comply with environmental requirements. Threat is also posed by hazardous household waste, which is frequently disposed of together with non-hazardous waste. During the implementation of Lithuanian National Pesticide Waste Management Programme for 2002 - 2005 1,023 tons of old pesticides were exported to Germany for neutralization (57 old pesticide repositories were cleaned and neutralized). However, problems related to the management of voltaic batteries, medical waste, and hazardous industrial waste are not yet completely solved. ${ }^{3}$

\footnotetext{
${ }^{3}$ Resolution of the Seimas of the Republic of Lithuania on Approval of the Ecological Security Assurance Programme, Official gazette Valstybès žinios, No. 117-4226, 01/10/2005.
} 
The largest sources of radionuclide pollution in Lithuania are the Maišiagala Radioactive Waste Storage Facility and Ignalina Nuclear Power Plant (INPP). Technical accidents and natural phenomena, which have a negative impact on the environment and human health, are recorded every year. There are over 930 potentially dangerous objects and 465 hydrotechnical constructions in the state. Up to 140 incidents are registered every year, 50 of which are considered extreme (most frequently the accidents occur during the transportation or storage of chemical substances, oil and its products). During the drought over 1,000 peat bog, peat grassland, and forest fires are registered, forest areas damaged by pests and diseases are constantly detected and due to active karstic processes up to 70 new sinkholes appear in the karst region of Northern Lithuania every year. Due to global climate change, natural disasters and calamities such as floods, earthquakes, droughts, etc. become more frequent and cause damage to the environment, people, and economic growth of the state. Every year great floods inundate large areas in the lower reaches of the river Nemunas.

The chemical industry is one of the largest and most important EU economy branches which develops necessary products for other sectors and makes strong contribution to the EU economic development. The current EU regulation of the use of chemical substances is criticised as being unfavourable to economic growth, hindering innovation and failing to ensure effective control of threats posed by chemicals. The current threat evaluation process lasts a long time and the annual evaluation comprises only some of the substances. At the moment more attention is paid to threats posed by newly appearing substances rather than those currently available in the market (the new substances are considered to be those that came onto the market in 1981 - around 3,000 types of substances; the number of chemicals that were begun to use before 1981 is over 100 thousand). The introduction of Registration, Evaluation, Authorization and Restriction of Chemical Substances (the REACH system) will ensure the protection of human health and the environment from the damaging impact. This system will impose the same requirements for all chemicals substances. Before producing and supplying the substances to the EU market manufacturers and importers will be required to evaluate the possible risks from chemicals and to provide for the means of their elimination. 


\section{Conservation of Natural Resources: Guarantee of Ecological Security and Sustainable Economic Development}

The conservation of natural resources is understood as the use of resources with respect to environmental, economic, and social objectives of society by opening up possibilities to achieve global welfare for the current and future generations without crossing the permissible environmental impact limits. Thus, it is necessary to create favourable conditions for the rational use, protection, restoration, and increase in the abundance of natural resources. In order to ensure economic development, it is necessary to conserve natural resources - the increase in volume of goods and services must be twice as rapid as the use of natural resources for their development. Although Lithuania has formed a legal and economic basis for encouraging the conservation and protection of natural resources, reduction of the environmental impact, increase of energy efficiency and the use of renewable energy resources, the environmental quality, however, still does not meet the requirements for the sustainable economic development.

Water resources determine the possibilities and conditions for the economic development. Water is the key factor, which is responsible for the state of ecosystems, therefore, water quality security remains one of the most crucial conditions for ensuring both the national, and ecological security. Around 64 per cent of Lithuania's surface water bodies are affected by anthropogenic activities. The surface wastewater (rainwater) management infrastructure is poorly developed, thus, large amount of this wastewater remains untreated and goes to surface water bodies which has a great negative impact on their state.

Underground water as one of the earth entrails resources is the main source of drinking water in Lithuania; therefore, its protection is one of the main means for ensuring ecological security. Groundwater is poorly protected from the anthropogenic impact and is mainly affected by non-point source pollution. Drinking water quality is especially relevant in the countryside areas where people use water from dug wells. Around 1 million of Lithuanian residents use water from dug wells that is frequently polluted with nitrates and poses a risk to human health.

The Constitution of the Republic of Lithuania stipulates that the right of ownership of the entrails of the earth exclusively belongs to the state which emphasizes the importance of the earth entrails resources to the national life. The abundance in mineral resources and abilities to use them determines the rate and extent of the state's development as well as life standards. Lithuania has explored in detail 17 types of mineral resources, 9 types of which (limestone, dolomite, sand, gravel, clay, chalky marl, sapropel, and oil) are being used. The guide value of explored mineral resources made up LTL 56 billion in 2006. These mineral resources are mainly used in the construction materials industry and road development and are among the most important world's 
mineral resources according to their consumption (22 million tons, which is the largest amount consumed among all resources) and economic value (according to it they are out topped only by oil, gas, and coal). There is a threat that the development of the construction business will result in a further increase in the amount of mineral resources per capita (the current amount is around 4 tons per capita) which may achieve the level of the industrial countries (20 tons per capita) and thus, threaten both national, and ecological security.

The Lithuanian forest resources are sufficiently balanced so as to satisfy the public needs and foster forestry development. Forests now cover around 2.12 million ha (32.5 per cent) of the state's territory and the area of forests has been constantly increasing in the last years. However, Lithuanian forests are every year affected by various factors. In order to minimise the damage done by fires, the national system of forest fire prevention measures has been developed and maintained, however, due to unpredictable human activities which poses threat to the natural environment, it becomes increasingly difficult to prevent fires and protect the environment from the consequences.

Fish resources are among the crucial food and recreation resources. Lithuania's sea fisheries include the Atlantic Ocean and the Baltic Sea. The total amount of fish caught in these waters make up around 150 thousand tons, although the annual fishing quotas for Lithuania imposed by the EU Council are set at around 30 thousand tons. Due to the underdeveloped fishing infrastructure, growing fuel prices, unstable fishing partnership with third countries, and diminishing resources of certain fish species only half of the set amount is caught. The supply of fresh fish does not meet the demand of the state's customers.

Natural environment resources, i.e. biodiversity and natural landscape, as the key recreation resources that form the basis for healthy living remain among the most crucial resources of Lithuania. Biodiversity is threatened by the changing farming methods both in agricultural, and forestry sectors and the growth of invasive species. It is highly important to protect the shore of the Baltic Sea, since global climate change, rise of the ocean level, and diminishing sand resources cause shore erosion. The development of the Baltic Sea shores is greatly influenced by the growth of sea industry which has a negative impact on the shore formation processes.

Lithuania imports around 90 per cent of their primary energy. One of the most important reasons for the inefficient use of energy resources in Lithuania is that the majority of public buildings have poor thermal characteristics and their heating requires great amount of energy. The use of ecologically clean renewable energy resources, such as geothermal energy (i.e. heat energy produced in the entrails of the earth) and wind energy, for heat and electricity production is still insufficient. ${ }^{4}$

The major task which has to be accomplished in order to meet national

\footnotetext{
${ }^{4}$ Resolution of the Seimas of the Republic of Lithuania on the Approval of the Programme of Conservation of Natural Resources, Official gazette Valstybès žinios, No. 30-1095, 10/03/2007.
} 
security requirements in the face of the risk to ecological security is to ensure sustained and rational use, protection and increase in the abundance of natural resources that are crucial for the functioning of the state by creating conditions for sustainable economic development.

\section{Sources of Threats to Ecological Security and Environmental Protection Measures}

Threats to ecological security may arise due to the following causes:

- Technical causes (e.g. an accident in the Ignalina NPP, accidents in nuclear power plants of the neighbouring countries, accidents in companies, storages or other buildings where hazardous chemical substances and preparations are produced, processed, stored, or their waste is treated, fires in potentially explosive objects, accidents occurring when transporting radioactive or other hazardous chemical substances, preparations or their waste, gas main accidents, collapse of hydrotechnical constructions, oil extraction in the Baltic Sea);

- Natural causes (e.g. disastrous catastrophic hydometeorological phenomena, geologically hazardous phenomena, widespread forest and peat-bog fires, surge of plant vermins);

- Social causes (e.g. spread of dangerous contagious diseases or endemic sources of contagious diseases).

These threats may in turn cause damage to Lithuanian residents, fauna, and flora as well as pollution of the air, water, and soil. Thus, ecological security is a set of actions and measures for ensuring healthy and clean environment, minimum negative impact on the environment and human health and prevention of damage to people and the environment. Therefore, what we must accomplish in the field of water protection is to upgrade and expand the existing wastewater treatment facilities as well as construct new facilities meeting the EU requirements, renovate the sewage collection system, upgrade an infrastructure of the public drinking water supply networks, implement necessary technical and institutional measures in order to supply population with healthy drinking water and upgrade a system for water resource monitoring, laboratory analysis, data collection and assessment.

The objectives in the field of atmosphere protection are to reduce the greenhouse gas emissions into the atmosphere by introducing the system of pollution permits, introduce the latest technologies in large combustion plants and use facilities for treatment of combustion products, establish a system of vehicle pollution control, enforce economic and administrative measures to control pollution from the transport sector and introduce a model based system of air quality monitoring. ${ }^{5}$

\footnotetext{
${ }^{5}$ Press release of the Ministry of the Environment of the Republic of Lithuania: Climate Change and Lithuania, http://www.am.lt/VI/article.php3?article_id=6161, 03/09/2007.
} 
What needs to be done in the waste management sector is to close landfills that are not in compliance with the EU requirements and to establish modern regional municipal waste management systems, to establish a hazardous waste utilization system ensuring save to environment and human health handling of hazardous waste, prepare a programme for energy production from waste and start implementing this programme, introduce up-to-date spent nuclear fuel treatment and storage technologies and explore possibilities for underground disposal of radioactive waste and to develop a radioactive waste management infrastructure based on modern technologies.

The objectives in the field of emergency management are to evaluate the preparation of the responsible state institutions to react to emergency situations and improve this preparation, increase the efficiency of forecasting droughts and floods in the lower reaches of the river Nemunas, establish seismic stations and carry out the seismic analysis of Lithuania and seismic division into districts, ensure proper use and maintenance of hydrotechnical constructions of dams; prepare preventive measures against forest and peat bog fires, investigate underground karstic cavities and draw a map of such cavities of the karst region of Northern Lithuania, ensure ecologically safe urban development with respect to karstic phenomena, improve the expedition and efficiency of eliminating the effects of emergencies, etc. By adopting preventive measures, this ensures the proper control of sources posing potential threats to ecological security.

\section{Assurance of Radiation and Nuclear Safety}

The priority Lithuania's national security trend in 2006 the was protection against radiation risk by ensuring nuclear and radiation safety and preventing possible terrorist attacks, illegal movement of nuclear and radioactive substances as well as unsafe operation or decommissioning of Ignalina NPP. The implementation of the PHARE project - Strengthening of Emergency Preparedness for Nuclear and Radiological Accidents in Lithuania - was completed in 2006, during which the legislative acts on emergency preparedness were reviewed with a view to avoid an ecological catastrophe, i.e. to ensure ecological security. During the implementation of the project information publications on how to act during radiation accidents were published in the Lithuanian and Russian languages, technical preparedness was improved and training methodology was developed. In 2006 the measurement equipment of radiation risk alert system (RADIS) was renovated. Moreover, the third Ignalina NPP Safety Improvement Programme (SIP-3) was prepared, which consists of 115 safety improvement measures that will be implemented in the period of 2005 - 2009.

One of the projects that required much funding was the preparation for moving not completely burnt nuclear fuel from the first block to the second block of the Ignalina NPP, the construction of which was completed in 2006. 
The SIP-3 programme pays much attention to the improvement of physical safety of the NPP, new safety means are being acquired and introduced. ${ }^{6}$

In order to ensure radiation safety when managing radioactive waste, the strategy on radioactive waste management is being implemented which provides for the objectives of radioactive waste management infrastructure development and the operational programme of the State Enterprise Radioactive Waste Management Agency for 2006-2008. In 2006 the implementation of the PHARE project Assessment and Improvement of the Safety of the Maišiagala Repository, designed for the improvement of the safety of Maišiagala radioactive waste disposal site, was completed. The pile of radioactive waste was covered with a special set of additional coverings, new security fences were built and physical protection equipment was installed. Constant environmental monitoring of Maišiagala radioactive waste repository located in Bartkuškis Forest of Sirvintos Region is carried out. Having performed geological examination and monitoring of the potential site of a near-surface repository in the territory of Ignalina NPP the exploration of Stabatiškès site was completed and the report on the environmental impact assessment, which includes Apvardai, Galulaukè and Stabatiškès sites, was prepared and approved by relevant state and intergovernmental institutions. ${ }^{7}$

It can be stated that Lithuania has properly established the legal framework for the radioactive waste management, properly arranged works of the decommissioning of the Ignalina NPP, approved the national strategy on radioactive waste management and its implementation scheme and developed a system for managing the lost radioactive sources. However, much work is still to be done: it is necessary to choose a place for a near-surface repository, to design and construct it, ensure the implementation of the decommissioning plan and the provision of the necessary funds, improve the safety of the Maišiagala radioactive waste repository, continue co-operation with the neighbouring countries regarding construction of nuclear energy objects, and to implement recommendations of the International Atomic Energy Agency (IAEA) by developing the process of choosing places for repositories and their construction.

How are we going to improve nuclear safety in Lithuania? Europe has already reached the highest level of nuclear safety. European countries follow the nuclear safety requirements imposed by the International Atomic Energy Agency (IAEA), meet safety standards, follow other technical documents and apply advanced experience. In each country nuclear safety is ensured by the national legislation and requirements and efforts are made to achieve constant improvement of nuclear safety in the future. In 2006 a report on the harmonisation of nuclear safety of reactors was presented in Brussels. It was established

\footnotetext{
${ }^{6}$ Press release of the Radiation Protection Centre: Assurance of Radiation and Nuclear Safety, 09/02/2005

${ }^{7}$ Press release of the State Nuclear Power Safety Inspectorate: How are we Going to Improve Nuclear Safety in Lithuania?, No. (21.4.11)22.1-360, 26/05/2006.
} 
that 51 per cent of national requirements applicable in European countries meet the recommended standards. The European nuclear power plants have already implemented 88 per cent of the recommended standards and harmonisation of reactor safety regulation is to be finished by 2020 .

\section{Ecological Security Problems and Risk Factors}

Atmospheric pollution by greenhouse gases is one of the major causes for the climate change and its minimization is a task for the whole international community. In the period 1990 - 2005 greenhouse gas emissions in Lithuania decreased by more than a half (from 48 to 22 million tons). Around 35 per cent of greenhouse gases are emitted by AB Mažeikių Nafta and other companies of the energy sector; transport contributes to 21 per cent of emissions and larger industrial enterprises, such as AB Achema, AB Naujasis kalcitas, AB Akmenès cementas and others are responsible for 22 per cent of emissions; the agricultural sector contributes to 18 per cent of greenhouse gas emissions, whereas the remaining part, i.e. 7 per cent, is emitted by waste management and water treatment plants. As compared to the great countries, the annual amount of greenhouse gas emissions in Lithuania make up only a small part, i.e. 0.05 per cent of the global amount. The USA is responsible for 20 per cent of the world's greenhouse gas emissions, which means that the amount of emissions in this country makes up 25 tons per capita, whereas the emissions in the EU and Lithuania amount to 10 and 4 tons per capita respectively.

As well as other 164 countries Lithuania has ratified the Kyoto Protocol to the United Nations Framework Convention on Climate Change and follows the requirements set out therein. According to the Protocol the EU committed to reduce its emissions of greenhouse gases by 8 per cent below 1990 levels until 2012. One of the most acceptable measures for reducing greenhouse gas emissions in the country is energy saving by introducing new technologies in the production sector, modernizing power plants and boiler houses, more broadly using renewable energy resources and renovating apartment buildings with a view to increase their energy efficiency. When meeting the requirements of the Kyoto Protocol some problems might be encountered in 2009 when having decommissioned the Ignalina NPP more fossil fuel will be used for the production of electricity, which might increase the amount of greenhouse gas emissions into the atmosphere. With a view to implement the Apartment Residential Buildings Modernization Programme it is planned to renovate around 80 per cent (15 thousand) of old apartment buildings until 2020. This will allow saving around 30 per cent of heat energy and reducing greenhouse gas emissions into the atmosphere by up to 400 thousand tons per year. The negative impact of the global climate change on agriculture became more apparent in the last years, which increased the importance of managing the risk posed by these phenomena. The current risk management system based on 
the reimbursement of insurance premiums and indemnification for damages incurred due to natural disasters is not effective.

The Greenhouse Gas Emission Trading Scheme (EU ETS), which is a measure for reducing atmospheric pollution, has commenced its operation in the European Union. 93 Lithuanian industrial enterprises were allowed to trade the saved pollution permits if they released smaller amount of pollutants into the atmosphere than had been allowed. The European Commission approved the National Tradable Pollution Permits Distribution Plan for 2005 - 2006, according to which Lithuania is allowed to emit 34 million tons of greenhouse gases during the period of 3 years (in 2005 the emissions quota was 13.5 million tons and Lithuania released only 6.6 million tons greenhouse gases; in 2006 the emissions quota was 10.6 million tons while the amount of actual emissions made up around 7 million tons).

A highly effective way to minimize the amount of greenhouse gases in the atmosphere is to increase forest cover. Forests absorb carbon dioxide and release oxygen which makes them the best air cleaners. Around 196 thousand hectares of abandoned land or land which is unsuitable for agriculture should be covered with forests. In the period between the years 2002 - 2006 the forest cover increased by 1.3 per cent and plans are made to increase it up to 3 per cent within the forthcoming 20 years. Such extraordinary phenomena as mushrooms or violets growing in forests in the middle of winter are related to climate change. In fact, climate change is responsible for around 90 per cent of all emergencies related to nature. In the future, global warming may cause heavy showers, long-term droughts and sudden thaws which in turn might change the soil structure. All this would have an enormous impact not only on the Lithuanian nature, but also on the economic and social development of the state as well as well-being of every person.

The impact of climate change will be most strongly felt by the coast of the sea. The current rate of the Baltic Sea level rise along the Lithuanian coast is $6.5 \mathrm{~mm}$ per year. This poses a threat that at the end of the $21^{\text {st }}$ century the coastline will have significantly changed and not only the coast of the sea, but also a part of the coast of the Curonian Lagoon will be flooded. During the last decades such a threat has already been faced by the beaches at Palanga, the sand of which has been washed away and the ridge of the beach has been dramatically narrowing. The sea-level rise, storms and hurricanes will continue damaging the coasts and the beaches of the Baltic Sea, which will require great investments in coastline management. Scientists have to assess in a timely manner the impact of the climate change on the country's ecosystems, biodiversity, water resources, forestry and agriculture, as well as human health and other spheres. ${ }^{8}$

According to the opinion survey on global warming and climate change carried out among Lithuanian residents, large part of the population (49.5 per

\footnotetext{
${ }^{8}$ Press release of the Ministry of Environment of the Republic of Lithuania: Climate Change and Lithuania, http://www.am.lt/VI/article.php3?article_id=6161, 03/09/2007.
} 
cent) is willing to contribute personally to attempts to reduce climate change. 89.6 per cent of respondents acknowledge climate change as a problem and claim that this process is mostly caused by industrial pollution; 19.2 per cent of respondents hold an opinion that one of the most important factors responsible for climate change is transport pollution whereas only 7.7 per cent of energy specialists are of the same opinion. However, over one third of the population tend to assume that all factors equally contribute to the process, which is quite understandable since people experience warmer winters, irregular seasons, feel negative influence on animals, landscape, and sea environment. ${ }^{9}$ We could significantly contribute to well-being of future generations by saving energy, planting trees, using ecological means of transport, renovating apartments, participating in international initiatives on reducing climate change, using energy saving equipment and by at least occasionally going without automobiles.

The modern world is using more raw materials than ever before and in such great quantities that it frequently becomes quite difficult to justify this excessive consumption. The current energy supply is based on fossil fuel, the consumption of which has increased five times as compared to 1980 levels. Research shows that the global energy consumption tends to double which brings up a question about how long the reserves of fossil fuel will last and how the environmental protection problems related to the greenhouse effect will be solved. The global $\mathrm{CO}_{2}$ emissions into the atmosphere amount to 22,000 tons per year and this amount keeps constantly increasing thus posing threat to global climate stability. The greenhouse effect is the main energy related problem of today. Due to a more rapid temperature change, ecosystems fail to adapt to the changing climate (global warming is pushing habitats towards the North) and organisms fail to migrate to more suitable climate zones so quickly. It is necessary to control this process in respect to the needs of the natural environment. There is no doubt that the minimization of $\mathrm{CO}_{2}$ emissions is a costly process; scientists estimate that the costs of minimization will amount to USD 5 per ton, however, as compared to pollution minimization costs and with regard to irreversible consequences of pollution, this should hardly be discussed. The long-term prosperity of society can only be ensured by sustainable energy development, i.e. by ensuring that energy production and consumption regards economic, social, and environmental protection aspects and by replacing currently used energy resources with renewable energy resources. The use of renewable energy resources is especially relevant to Lithuania, since it lacks primary energy resources.

In 2006 the trends in change of ecological risk factors in Lithuania were similar to those of 2005. The risk factors which contributed to the change of the state's ecological condition in the field of the atmosphere protection included rapidly growing number of automobiles, inefficient city traffic control

\footnotetext{
${ }^{9}$ Press release of the Ministry of Environment of the Republic of Lithuania: Large Part of the Population is Willing to Contribute to Attempts to Reduce Climate Change, http://www.am.lt/VI/article.php3?article $\mathrm{id}=6158 \% 20-\% 2014 \mathrm{k}, 26 / 02 / 2007$.
} 
systems, and the lack of bypasses, whereas the risks in the sector of water consumption safety were posed by worn out central water supply networks, insufficient quality of the drinking water and well water, as well as the great number of territories polluted by waste and landfills that do not comply with the EU requirements.

In 2006 the number of emergencies, which resulted in the pollution of the environment increased. Among the most notorious emergencies two disastrous fires should be mentioned: the Curonian Spit fire during which over 250 hectares of dwarf mountain pine forest was burned and the fire which broke out in the territory of AB Mažeikių Nafta. In 2006, 305 people were killed in fire in Lithuania. This rate is one of the highest among the EU member states and tends to increase. The number of accidents and incidents during which only small damage to the environment was done also increased: in 200587 incidents were registered, whereas in 2006 their number amounted to 102. In the majority of cases (61 of all cases) these incidents were related to oil products and chemical substances.

The meteorological conditions, such as the lack of rain, high air and soil temperature, and great solar radiation inflow, which prevailed in summer 2006, caused drought in many Lithuanian regions. Severe drought settled over $1 / 3$ of the state's territory which posed extremely great forest fire risk and caused surface water bodies to sink which causes concern since droughts tend to break regularly and have become more frequent in the last years.

\section{Instance of Assessing the Primary Environmental Pollution at the Place of Emergency or Accident}

On 15 September 2006, after midnight, a fire broke out in Molètai tire storage facility. Specialists took air samples in the place of an accident in order to estimate the concentration of volatile organic compounds. Air samples were taken at a 30 and 300 metre distance from the burning storage at the leeward side and analysed in the laboratory. It was established that the concentration of ethylbenzene in the samples taken at a 30 metre distance from the fire exceeded the maximum allowable concentration (MAC) from 2.5 to 5.5 times. The concentration of other compounds, such as benzine, toluene, and 1.2.4-trimethylbenzene, the MAC of which was established in the Lithuanian hygiene norm HN 35:2002, did not exceed the allowable quantities. The concentration of pollutants in the samples taken at a 300 metre distance did not exceed the MAC.

According to the data of the Lithuanian Hydrometeorological Service, at the night of 15 September the weather in Lithuania was determined by the high pressure area which brought no rain and only light variable wind. During the 
inspection of the place of accident east and northeast wind blowing at the speed of up to $1 \mathrm{~m} / \mathrm{s}$ was measured nearby the source of fire. Such weather conditions prevented the dispersion of pollutants. The tire storage was situated in the outskirts of Molètai, which also blocked the dispersion of hazardous substances over the town. Thus, conclusions may be drawn that near the source of fire the concentration of ethylbenzene exceeded the MAC, whereas the concentration of volatile organic compounds measured at a 300 metre distance in the leeward side did not exceed the maximum allowable concentration. Therefore, there was no need to monitor the air of the environment after the fire was extinguished and the source of pollution was eliminated. However, it would be difficult to imagine the ecological outcomes and the extent of threat to human health in case the weather conditions were favourable to the dispersion of pollutants over the town. Failure to ensure ecological security might cause great damage to the living environment. ${ }^{10}$

\section{Ecological Insurance: A Means for Minimizing the Risk}

Ecological risk insurance is currently understood as a legal relationship based on a law or a contract, the essence of which is financial reimbursement to third persons (either natural persons or legal entities) for the economic damages incurred due to certain accidents that caused emergency and unexpected environmental pollution. Ecological insurance is only possible in case there is a sufficient number of policyholders who might incur such damages and want to reduce the risk of possible losses by building up corresponding insurance funds and in case there are insurance companies that are willing to insure the risk. Twenty years ago neither in theory nor in practice, bank and insurance operations provided for the ecological risk. The World Bank was the first to raise the issue of ecological security in 1980s. The rate and extent of raising ecological awareness became one of the most important areas of banks' competitive activities. Banks, insurance companies, and investment funds of the Western countries rationally adapted their activities to the requirements of the changed market situation and began to direct their efforts towards the rapid increase of ecological investments, development and introduction of new bank products related to environmental quality maintenance, and to emphasize ecology as a motive for their activities. There is no doubt that ecology will be that factor which will give an impetus for quality changes in the banking sector and the processes of obtaining environmental benefits and environmental quality maintenance will become increasingly important objectives of banking institutions.

\footnotetext{
${ }^{10}$ Note of the Ministry of Environment of the Republic of Lithuania on the Assessment of the Primary Environmental Pollution at the Place of Emergency or Accident, http://aaa.am.lt/VI/files/0.608884001158 740632.doc, 15/09/2006.
} 
The market of banking services is closely related to the market of insurance services and thus, insurance companies have quickly reacted to the increased relevance of ecological problems and the increased value of environmental dimensions. The environmental damage insurance has now become a separate type of insurance which covers any activity by combining separate insurance policies. Through the provisions of insurance contracts the insurance sector greatly influences safe activities of the companies directed towards environmental protection. The financial liability for environmental damage has greatly increased during the last decade. It now includes paying cleanup costs, liability for damage to persons or property, reimbursement for legal representation costs, losses incurred due to temporary suspension of business, decrease in third party's property value due to the impact of pollution, and contract liabilities. This type of insurance has become more easily available. ${ }^{11}$

\section{Eco-Labelling: A Preventive Measure for Ensuring Ecological Security}

Eco-labelling is a method for certifying those products and services that cause less damage to the environment and health, than other products and services of the same group. Consumers can recognize such products from an ecolabel, i.e., a graphic symbol on the product's label, advertisement, etc. Labelling is not obligatory; it is a voluntary choice of producers, importers, or sellers. In order products could be marked with ecolabels, they have to meet certain requirements. Eco-labelling contributes to environmental pollution minimization and protects health (ecolabels are attached to the products that are made using raw materials and technologies that cause less air, water, and soil pollution and produce less waste; these products and their waste cause no harm to human health and the environment). Eco-labelling also saves natural resources, since the established criteria consider the possibilities of waste management and secondary use as well as the amount of packaging. Moreover, when manufacturing and using the labelled products, less electric power, water and smaller amounts of other resources are used. Eco-labelling allows consumers a possibility to choose products and services that cause less damage to the environment and thus, contribute to the minimization of harm done to the environment and health. It also boosts the competitiveness of industrial enterprises: it contributes to the reduction of energy and raw material consumption per production unit, thus, enterprises can increase their productivity, whereas smaller environmental taxes also reduce cost price of production. Great favour of consumers shown to the environment and environment friendly products open up new possibilities to the companies. This tendency is not yet very clear in Lithuania but in the EU old-timers, where much attention is paid to the

${ }^{11}$ Čiegis R., (note 1) 
protection of the environment, only the companies that take the above criteria into consideration can get into and successfully compete in the market.

It is necessary to mention the producers' duty to ensure product safety. Products supplied to the market have to be appropriately labelled and provide consumers with all the necessary information so that they could assess the product related risk which might be faced during the whole term of use. Having found out that a product is not safe, a producer immediately informs consumers about it and undertakes to remove the product from the market according to the established procedure and to reimburse consumers for the damage incurred due to the use of an unsafe product. The Law on Product Safety of the Republic of Lithuania establishes general requirements for regulating and carrying out the inspection of product safety, the principles of state and public control of product safety, the procedure for providing and communicating information about dangerous products, and the duties and liability of producers, sellers and suppliers of services for placing dangerous products on the market of the Republic of Lithuania. ${ }^{12}$

\section{Tasks, Implementation Measures and Expected Results of the Ecological Security Assurance Programme}

The objectives set down in the National Ecological Security Assurance Programme, are to reduce ecological risk, prevent the negative impact on the environment and to set the national priorities in the sphere of prevention of emergencies. In order to implement the above objectives, it is necessary to ensure ecological security by securing sustainable economic development and to reduce the negative impact of an emergency on the environment and residents. Improving emergency preparedness, making up the set of financial, technical and other measures for the forecast and management of emergency situations, and adopting legal and institutional measures for encouraging the use of safer (less environmentally hazardous) ways of production and introduction of technologies, will allow the successful implementation of the EU requirements in the sphere of pollution prevention. Collection and analysis of reliable information and its timely disclosure to the public will encourage the cooperation with neighbouring countries in the spheres of ecological security and pollution prevention and legal and institutional conditions for mutual coordination of actions of the responsible institutions will allow ensuring ecological security.

The programme implementation measures in the filed of water protection are related to modernization of wastewater treatment facilities, the development

\footnotetext{
${ }^{12}$ Environment Information Centre, Eco-labelling, http://www.apicentras.lt/?pid=93, 2007.
} 
of the infrastructure of the public drinking water supply network and the improvement of the system for water resource monitoring, laboratory analysis, data collection and assessment. The objectives in the field of the atmosphere protection are to reduce the greenhouse gas emissions into the atmosphere, introduce the latest technologies in large combustion plants and use facilities for treatment of combustion products, establish a system of vehicle pollution control, enforce economic and administrative measures to control pollution from the transport sector and introduce a model based system of air quality monitoring.

What needs to be done in the waste management sector is to develop modern regional municipal waste management systems and to close landfills that are not in compliance with the EU requirements. It is necessary to establish hazardous waste collection and management systems, which would ensure save to environment and human health handling of hazardous waste, prepare a programme for energy production from waste and start implementing this programme, introduce up-to-date spent nuclear fuel treatment and storage technologies and explore possibilities for underground disposal of radioactive waste and develop a radioactive waste management infrastructure based on modern technologies.

The objectives in the field of emergency management are to evaluate the preparation of the responsible institutions to react to emergency situations, increase the efficiency of forecasting droughts and floods in the lower reaches of the river Nemunas, establish seismic stations, ensure proper use and maintenance of hydrotechnical constructions of dams; prepare preventive measures against forest and peat bog fires, investigate underground karstic cavities and draw a map of such cavities of the karst region of Northern Lithuania, ensure ecologically safe urban development with respect to karstic phenomena, prepare investment projects for preparedness to react to accidents in the Baltic Sea, to carry out an additional assessment of the environmental impact of operation of oilfield D-6 facilities, etc. ${ }^{13}$

Having implemented these programme measures, the state will be properly prepared to ensure maximum ecological security, will adopt preventive measures and will properly control the sources posing potential threat to ecological security.

\section{The Civil Protection and Rescue System of the Republic of Lithuania and its Objectives}

The aim of the Civil Protection and Rescue System is to prepare the public for emergency situations, i.e. to ensure smooth transition from ordinary

\footnotetext{
${ }^{13}$ Resolution of the Seimas of the Republic of Lithuania on Approval of the Ecological Security Assurance Programme, Official gazette Valstybès žinios, No. 117-4226, 01/10/2005.
} 
activities to behaviour under emergency circumstances and to minimize the economic losses incurred by the state in case of emergency situations, to save lives, maintain human health, protect property and the environment, to foster the initiative of the public in these areas and enhance confidence in the activity of the civil protection and rescue system.

The Civil Protection and Rescue System of the Republic of Lithuania comprises the Government Emergency Commission, Fire and Rescue Department under the Ministry of the Interior of the Republic of Lithuania and its subordinate agencies, ministries, state and municipal institutions, fire prevention and other civil protection services of municipalities, economic entities and agencies, and the environment monitoring and laboratory control network

The tasks of the Civil Protection and Rescue System are as follows:

- To warn the population of the imminent emergency, inform of its possible effects and measures to respond thereto;

- To undertake emergency prevention;

- To organise the supply of the population with individual protection kits and collective protection equipment;

- To carry out the reconnaissance and marking of the hazard area;

- To extinguish fires and carry out rescue operations;

- To maintain public order in the disaster area and provide medical aid and carry out public health care in the event of an emergency;

- To evacuate the people and property from the territories at risk and carry out sanitary treatment and other decontamination measures;

- To organise provision of the victims with temporary accommodation and supplies and make arrangements for the burial of the dead;

- To organise the restoration of disrupted provision of essential municipal services and provide assistance to preserve vital establishments;

- To stockpile vital supplies;

- To train chief officers, personnel, civil protection and rescue system forces and the population in actions in the event of an emergency;

- To investigate and analyse the causes of disasters ${ }^{14}$.

In Lithuania there are a number of sources that can potentially cause the appearance of emergency situations, death of great number of people or damage health. These sources include the Ignalina NPP, over 250 objects related to dangerous chemicals, transportation of hazardous chemical substances, traffic system, oil industry and oil pipeline networks (the possibility of terrorist acts and diversions could not be dismissed either).

Emergency situations can appear because of:

- Natural causes, denoting drastic changes of climatic conditions causing natural disasters, widespread forest and peat-bog fires, geologically hazardous pheno-

\footnotetext{
${ }^{14}$ Press release of the Fire and Rescue Department: Civil Protection and Rescue System, http://www.vpgt. lt/index.php?-1847704799, 2007.
} 
mena, especially dangerous or mass epidemics

- Technical causes, denoting disorders of various technological processes which cause fires, explosions, discharge of chemical or radioactive effluents, collapse of buildings, transport, energy system, main pipe-line accidents of various types and other disasters likely to happen in industrial objects and communications systems;

- Ecological causes, denoting factors leading to changes in the condition of the land, composition and properties of the atmosphere, and the state of the hydrosphere;

- Social, denoting mass riots and disturbances, blockades, provocations, subversive activity, acts of terrorism, also military actions in the territory of the Republic of Lithuania or in a neighbouring state.

Emergency situations could also arise due to an accident in the Ignalina NPP, accidents in nuclear power plants of the neighbouring countries, nuclear explosions, accidents occurring when transporting radioactive substances (waste), accidents in companies, storages or other buildings where hazardous substances are produced, processed, stored, loaded or neutralized, railway, aviation, sea transport, and road accidents, gas main and oil pipeline accidents, factory fires and explosions, forest and peat bog fires, natural disasters, calamities and hydrological phenomena (such as strong winds, snowstorms, heavy mist, broken embankments, flooded cities and other residential areas).

Lithuania has developed and elaborated on an emergency management system, developed a computer information system of the Register of Hazardous Objects and Objects of State Significance, the aim of which is to collect information about the objects of the Republic of Lithuania and objects of state significance in a standard electronic format, to use this information and submit it as a basis for meeting civil protection objectives. The Register contains information on the objects of state significance (approved by Resolution No. 1343 of the Government of the Republic of Lithuania of 9 November 2001), hazardous objects (approved by the Order No. 221 of the Minister of Environment of the Republic of Lithuania of 19 July 1999) and hydrotechnical constructions, i.e., structures and facilities for using water resources and protecting the environment from the damaging impact (embankments, viaducts, hydroelectric power plants, navigation structures, etc.) and constructions causing flood threat. The managing and central institution which administrates the Register is the Fire and Rescue Department under the Ministry of the Interior of the Republic of Lithuania whereas the regional institutions responsible for the management of the Register are civil protection departments under county governor's administrations. The National Security Strategy approved by the Seimas provides for establishing a joint civil protection and rescue institution under the Ministry of the Interior of the Republic of Lithuania. The system is currently being developed. 


\section{The Prevention and Reduction of Environmental Pollution by Asbestos}

Because of its qualities, such as resistance to chemical substances and fire, low thermal and acoustic conductivity, and asbestos was widely used for production of construction materials and other items (e.g. cement roofing sheets, non-pressure sewage pipes, and thermal insulation materials used in boiler houses and furnace ducts, asbestos cloth used for making fireproof clothing and production of various screens, electrical wire insulation, and brake pads and linings). As of 1961, 700 thousand tons of asbestos was used in Lithuania for making asbestos cement products. The majority of this amount was used for producing cement roofing sheets and pipes. Therefore, it can be stated that asbestos was used for nearly all roofs of Soviet buildings, boiler houses, and furnace ducts. Asbestos was imported to Lithuania from Russia. Following the EU requirements, on 1 January 2005 Lithuania banned the use of asbestos and its products. However, due to wide use of asbestos, its fibres released from damaged asbestos-containing products still pose a threat to public health. Since the information about asbestos-containing products, their deterioration, amounts, and areas most contaminated with asbestos is not systematically collected, it is difficult to estimate the scope of work to be done in order to remove asbestos from the environment, the required financing and to determine priorities of removing asbestos-containing products. In order to collect reliable data, it is necessary to employ qualified specialists who could be able to identify asbestos-containing products and assess the risk to public health posed by these products. According to the data of the national waste inventory, in 2004 around 3,000 tons of asbestos-containing waste was produced and disposed of in landfills, whereas in 2005 this amount made up 738 tons. Following the provisions of instructions for construction, operation, closure and maintenance of landfills, waste disposal in landfills that do not comply with the EU requirements will be prohibited as of 16 July 2009. After the closure of these landfills asbestos-containing waste could be disposed of in Vilnius construction waste landfill and in two regional landfills - Alytus and Kaunas (Lapès) landfills. It is planned to build separate sections for the disposal of asbestos-containing waste in these landfills; however, technical requirements for the disposal of asbestos-containing waste in landfills have not yet been set in Lithuania which does not allow ensuring safe management of this waste. The risk posed by asbestos is most severely felt by the workers who carry out building demolition and repair works and works related to removal or asbestos. Requirements for protection of workers against the risk posed by asbestos and preventive measures against potential risks to health are set down in the regulations of work with asbestos. Following the methodology on the asbestos fibre concentration in the air, the accredited laboratory measures the amount of asbestos in the air of work environment. General competence requirements for companies carrying out the works of demolition and elimination 
of buildings in structures of which asbestos is found are also provided for the legal documents. The applicable legal acts still fail to ensure safe removal of asbestos-containing products from the air and safe management of asbestoscontaining waste. Since workers are not sufficiently informed or educated about the risk to public health posed by asbestos and acquainted with requirements for safe work with asbestos, it becomes difficult for them to identify asbestos-containing products when carrying out construction or demolition works and thus, asbestos-containing waste is not separated from other waste and might go to waste disposal and treatment facilities. Companies pursuing asbestos related activities quite frequently do not to follow the requirement set down in the regulations of work with asbestos, i.e. fail to inform the State Labour Inspectorate about the company's competence to carry out such works with respect to workers' safety and health and do not test the asbestos fibre concentration in the air of work environment.

Asbestos cement roofing is most commonly used in low-rise buildings in rural and regional areas where residents receive low income and do not have enough funds to replace this covering with non-asbestos roofing. Therefore, owners of apartment buildings and low-income families receive financial support for renovation of apartment buildings including roof overhaul and reconstruction. It is planned to make use of the financial assistance provided by the EU Structural Funds for this purpose. In order to boost energy efficiency of buildings and reduce energy consumption, the EU Structural Funds are to be used for financing the modernization of heat supply networks and renovation of apartment buildings where it is most needed as well as the renovation of public buildings. Nevertheless, this will only ensure removal of small amount of asbestos-containing products from the environment. Since the public is not sufficiently informed or educated about the risk to public health posed by asbestos and no mechanism for encouraging the removal of asbestos-containing products from the environment has yet been developed, residents, instead of using the services of companies that carry out asbestos removal works, tend to do such work by themselves and do not assign this job to qualified waste management companies.

Provisions for the prevention and reduction of environmental pollution by asbestos are applied to economic activities which involve the handling of a quantity of more than 100 kilograms of raw asbestos per year. Those who engage in such activities have to take the necessary measures to ensure that asbestos emissions into the air and asbestos discharges into the surface water bodies, are, as far as reasonably practicable, reduced at source. Solid asbestos waste has to be repeatedly recycled and processed or prevented altogether. Special requirements are imposed for the manufacture of asbestos cement, asbestos paper and card (e.g. all effluent arising in the manufacture have to be treated and reused by building circulating water supply systems). The monitoring of sources of asbestos pollution has to be done on a regular basis, i.e. the asbestos concentration at sources of pollution has to be measured according to the established order. The EU Council Directive on the prevention and reduction 
of environmental pollution by asbestos (87/217/EEC) lays emphasis on the importance of prevention and reduction of environmental pollution. Since asbestos has been listed among the first-category pollutants to be investigated on the grounds of their toxicity and of their potentially serious effects on human health and the environment, the marketing and use of blue asbestos and products containing blue asbestos fibres have been restricted and special provisions concerning the labelling of products containing asbestos has been imposed. Provisions have been laid down on the protection of workers from the risks related to exposure to asbestos and measures and requirements for the combating of air pollution from industrial plants have been adopted. The EU member states should take the measures necessary to ensure that asbestos emissions into the air, asbestos discharges into the aquatic environment, and solid asbestos waste are, as far as reasonably practicable, reduced at source and prevented. Therefore, it is advisable to allow enough time in order the industrial plants could implement the imposed measures.

Having assessed the risk posed by asbestos on public health and the current situation of the use of the asbestos-containing products and their removal from the environment the Government of the Republic of Lithuania prepared the asbestos phase-out programme which defines the objectives, tasks, legal, administrative and economic measures for the programme implementation. The measures provided for in the programme have to be implemented by 2013. The amended legal acts on the removal of the asbestos-containing products from the environment will include a requirement for provision of information on the asbestos-containing products and their safe removal from the environment at the building design stage, will define technical requirement for the disposal of asbestos-containing waste in landfills and ensure safe removal of the asbestos-containing products from buildings under demolition or reconstruction. The system for licensing the companies carrying out asbestos removal works and improving worker qualifications will tighten the control of the removal of the asbestos-containing products and will minimize the risk posed by asbestos on workers' health. The implementation of public information and education measures will improve the informing of the public on the risk posed by asbestos and the public will have sufficient knowledge on how to handle the asbestos-containing products and will more frequently use the services of companies that carry out asbestos removal works. The evaluation criteria for the programme implementation will ensure more efficient use of the assistance provided by the EU Structural Funds.

If asbestos-containing constructions, structures and products are not disturbed, this material does not pose any great threat. The risk is faced when such structures or products are disturbed, broken or processed, which results in the release of minor invisible fibres into the environment. The inhaled asbestos fibres scar tracheal tissues, which causes lethal cancer illnesses. Due to the exposure to asbestos, around 20 thousand cases of death due to lung cancer are registered in the European countries and according to its noxiousness asbestos equals arsenic and quicksilver. As far as in 1976 the International Agency for Research on Cancer included asbestos into the list of possible carcinogens as a 
noxious, cancer-causing material, however, many people are still exposed to asbestos and asbestos-containing products. Asbestos can be found in nearly all brake and clutch components of older means of transport, cranes, elevators, and other mechanisms, fire resistant walls and doors, paint and glue (used for tiles and floor tiles), ventilation equipment and pipelines (used as an insulation), heat and fire resistant textile products, microwave ovens, etc.

The EU Council adopted as many as eleven directives related to asbestos-containing products or waste. Due to great resistance of asbestos, human organism cannot discharge or dissolve it. Fibres that are longer than 8 micromillimeters and thinner than 1.5 micromillimeters are extremely hazardous since they can reach the farthest lung stems. Due to the wide use of asbestos in industry and domestic life, its fibres may be constantly found in the air of many places. Asbestos fibres can be detected in the lungs of nearly all people. The risk of illnesses caused by asbestos increases when a large amount of asbestos fibres are inhaled. Dust containing asbestos fibres is biologically aggressive. These fibres found in lung tissue cause uncontrollable proliferation of cancer cells. Illnesses caused by asbestos tend to progress, are lethal, and the first symptoms of such illnesses may be experienced only after 20 or 30 years. The Government of the Republic of Lithuania adopted a resolution on the restriction of import, production and use of asbestos and products containing asbestos which established the following:

- To ban the use of even or curly asbestos-cement slating sheets in residential houses and objects of social purpose as of 1 January 2001;

- To ban the use of even or curly asbestos-cement slating sheets in all newly built objects as of 1 January 2002;

- To ban the use of processed asbestos-cement fibre, mixtures containing large amount of asbestos and their products except for those used in civil aviation as of 1 January 2003;

- To ban the import of asbestos and production of asbestos-cement pipes and couplings as of 1 January 2004;

- Following the provisions of the EU legal acts to ban the marketing and use of asbestos-containing products and materials as of 1 January 2005 (Council Directive 1999/77/EC);

- As of 15 April 2006 the EU member states introduced tougher measures for the protection of workers from the risks related to exposure to asbestos at work (Council Directive 2003/18/EC amending Council Directive 83/477/EEC). ${ }^{15}$

Despite this legal progress the real problem of protecting people against the threat posed by asbestos when carrying out removal, demolition, maintenance and operation works still has to be faced.

\footnotetext{
${ }^{15}$ Order of the Ministry of Environment of the Republic of Lithuania on the Approval of Rules on Prevention and Reduction of Environmental Pollution by Asbestos, Official gazette Valstybès žinios, No. 702081, 23/08/2000; Asbestos phase-out programme (draft), www.am.lt/VI/files/0.941625001178192576. doc, 2007.
} 


\section{Conclusions}

1.Economic development has highlighted the global problems (poverty, military conflicts, etc.). These conflicts inflict environmental damage, and the damaged environment turn causes social conflicts. Therefore, in order to ensure ecological security, the occurrence of ecological problems should be analysed as the outcome of these processes occurring among the economic, social and environmental protection components of the state's development.

2.The main external threats faced by Lithuania remain momentary natural disasters, such as storms, lasting frost, downpours, strong winds, and fires breaking out in open areas. It is necessary to determine the preventive measures that would ensure possibilities for avoiding such threats.

3.The environmental quality still does not meet the requirements for the sustainable economic development. Wastewater treatment and management of the arising effluent still is a problem and the problem of specific waste management has not yet been solved. A central supply of drinking water is still not available to the majority of Lithuanian residents. Only effective use of the financial assistance provided by the EU Structural Funds can ensure that these problems will be solved. Therefore, it is necessary to develop administrative abilities to assimilate the financial assistance at all levels of the public administration.

4. The increase in the volume of goods and services must be twice as rapid as the use of natural resources for their development. Thus, it is necessary to create favourable conditions for the rational use, protection, restoration, and increase in the abundance of natural resources.

5.Sources of threats to ecological security have been defined but there is a lack of action and measures that would ensure preservation of safe and clean environment. Therefore, the state still faces risk to ecological security.

6.It is necessary to assess the effectiveness of emergency management. The responsible institutions are frequently only theoretically prepared to react to emergency situations; therefore, prevention training and education of the public starting at schools have to be set as programme measures in the strategic national documents. It is necessary to control sources posing potential threats to ecological security

7.In order to ensure radioactive safety during the treatment of waste, it is necessary to choose a place for a near-surface Maišiagala radioactive waste repository.

8.Economic, social, and environmental protection aspects should be taken into consideration when solving the issues related to energy production and consumption and replacement of currently used energy resources with renewable energy resources. The use of renewable energy resources is especially relevant to Lithuania, since it lacks primary energy resources. Therefore, it is necessary to comply with the state's strategic obligations in this area.

9.In 2006, the number of emergencies which resulted in pollution of the 
environment increased. In the majority of cases these incidents were related to oil products and chemical substances. Therefore, it is necessary to strengthen the control of these activities, analyse the experience of the EU member states and apply their practical knowledge in Lithuania.

10. Ecological risk insurance has to become more easily available. Through provisions of insurance contracts the insurance sector should greatly influence activities of the companies directed towards environmental protection. By making use of the potential of business centres and associated business organisations it is necessary to encourage the business sector to insure ecological risk.

11. The safety of products supplied to the market is not ensured and the activities of the controlling institutions are too passive (they mostly involve the analysis of consumers' complaints). The strengthening of product safety control should be based on the principle of the producer's responsibility.

12. It is necessary to strengthen the monitoring of the implementation of ecological security programme measures by defining exact indicators and amending them if necessary. This approach would ensure a more effective use of budgetary funds.

13. The risks posed by asbestos and its products to human health are especially relevant. Practical problems related to the assurance of protection against the threat of asbestos during its management are still faced. It is necessary to develop a programme for encouraging and motivating the public to remove asbestos from the living environment.

14. In order to ensure the safety of all Lithuanian residents, it is necessary to coordinate the measures for ensuring ecological security at both national and municipal levels.

\section{Literature}

1. Lietuvos Respublikos Vyriausybės nutarimas, Dèl ekologinio saugumo užtikrinimo programos igyvendinimo 2006-2010 metų priemonių plano patvirtinimo, Valstybès žinios, 2006-02-09, Nr. 16-552;

2. Lietuvos Respublikos Seimo nutarimas, Dèl ekologinio saugumo užtikrinimo programos patvirtinimo, Valstybės žinios, 2005-10-01, Nr. 117-4226;

3. Lietuvos Respublikos Seimo nutarimas, Dèl gamtos išteklių tausojimo ir apsaugos programos patvirtinimo, Valstybès žinios, 2007-03-10, Nr. 30-1095;

4. Lietuvos Respublikos aplinkos ministro įsakymas, Dėl aplinkos taršos asbestu prevencijos ir mažinimo taisykliu patvirtinimo, Valstybès žinios, 2000-08-23, Nr. 70-2081;

5. Lietuvos Respublikos Vyriausybès nutarimas (projektas), Dèl asbesto šalinimo programos patvirtinimo, 2007;

6. R. Čiegis, „Ekologinis saugumas: nauji iššūkiai planetai“, Strateginė savivalda, ISSN 1648-5815 Strategic Self- Management 2006 Nr. 1(3);

7. Lietuvos Respublikos aplinkos ministerijos pranešimas spaudai, Klimato kaita ir Lietuva, 2007-09-03; 
8. Lietuvos Respublikos aplinkos ministerijos pranešimas spaudai, Radiacinès ir branduolinès saugos užtikrinimas, 2005-02-09;

9. Valstybinès atominès energetikos saugos inspekcijos pranešimas žiniasklaidai, Kaip gerinsime branduolinę saugą Lietuvoje, Nr. (21.4.11)22.1-360, 2006-05-26;

10. Lietuvos Respublikos aplinkos ministerijos pranešimas žiniasklaidai, Nemaža dalis Lietuvos gyventojų linkę prisidèti prie klimato kaitos mažinimo, 2007-02-26;

11. Priešgaisrinès apsaugos ir gelbèjimo departamento pranešimas spaudai, Civilinès saugos ir gelbejimo sistema, 2007;

12. Lietuvos Respublikos aplinkos ministerijos pažyma apie pirmini aplinkos užterštumo ivvertinimą ekstremalios situacijos ar avarijos vietoje, 2006-09-15;

13. Aplinkos informacijos centras, Ekologinis ženklinimas, 2007. 